\title{
Beauty and Pain: Notes on the Art of Richard Selzer · David B. Morris
}

THE MODERN HISTORY of beauty contains a moment of profoundest change. In 1757 human understanding of the beautiful passed from philosophy and religion into the possession of psychology and aesthetics. It is a change from which we have still not recovered.

Edmund Burke-then an unknown Irishman in his twenties-is the theorist chiefly responsible for changing Western ideas of beauty. His Philosophical Enquiry into the Origin of our Ideas of the Sublime and Beautiful (1757) founded the infant discipline of aesthetics on a division as relentless and fatal as the Cartesian split between matter and thought. In the Enquirybeauty loses all its ancient (classical and Christian) associations with knowledge, truth, goodness, and wisdom. Plato, for example, considered beauty the proper goal of love. The true lover is a nascent philosopher-the true philosopher an enlightened lover-because the passion for individual beauty leads finally to the love of truth (philosophy) itself. "Man seeks to be near beauty," as Paul Friedländer summarizes the view espoused by Socrates, "because the soul's wings grow at the sight of beauty." In Burke's Enquiry the soul has lost its wings, and the lover has lost his soul. "We must conclude," writes Burke, "that beauty is, for the greater part, some quality in bodies, acting mechanically upon the human mind by the intervention of the senses." Beauty, it turns out, is whatever produces the sensation of love, and what produces the sensation of love is anything appropriately small, graceful, varied, soft, colorful, undulating, delicate, mild, sweet, muted, or elegant. It is not coincidental that most of these qualities meet in the female figure. For Burke, beauty (in a choice which would have baffled the Greeks) is exclusively feminine. Missing but implicit is the standard accoutrement of parasol and corset, lisp, fainting spells, and tears. "Beauty in distress," adds Burke, as if winking to the new entrepreneurs of sentiment, "is much the most affecting beauty." The beautiful here stands completely defrauded of any cognitive or spiritual power: helpless, domestic, and trivial. Burke believed that he had advanced knowledge by discovering the psychological laws and social purpose of beauty-as the force which unites solitary individuals in a community of love-but his real achievement was to reduce the beautiful to a list of arbitrary forms and qualities. It occupies the exhausted category which we find reserved today for movie stars, sunsets, rainbows, swimsuit competitions, old works of art, and little fuzzy animals who don't bite.

With such an inheritance, it is hardly surprising that beauty is no longer among the primary aims or subjects of serious art. Artists who elect to pursue the beautiful reclaim it-like Baudelaire and Picasso-through deliberate strategies of dismemberment. 
Richard Selzer in his brief story "Raccoon" narrates the first-person account of a surgeon who visits a female patient as she recovers from recent abdominal surgery. She ignores his tactful knock, secluding herself in the toilet at some secret act. Worried, violating her secrecy, the surgeon finds her seated, bent forward, with her arm plunged elbow-deep in her freshly opened incision. A razor blade lies on the floor. He hurries her back to bed, appalled, and hastily begins to suture the wound, all the while grasping for an explanation of the terrible scene he has witnessed. The woman remains calm. Then the surgeon experiences a moment of revelation: "All at once I knew what it was, what she was reaching for, deep inside. It was her pain! The hot nugget of her pain that, still hissing, she would cast away. 'I almost had it,' she said. 'You should have waited,' she said."

Pain, mysterious, elusive, compelling, is one of Selzer's recurrent subjects. As a practicing surgeon he might be considered a specialist in pain. Painlessness is now among our national obsessions: anesthesia has become, like television, a household god, and at the first sign of discomfort we rush for our pills and doctors. Suffering we prefer to entrust to professionals. What we ask from the professionals, prior even to cure, is something to kill the pain. For Samuel Johnson, Burke's great contemporary, pain was a one-word definition of living. Smallpox, toothache, childbirth, kidney stone, syphillis, and gout marked the ages of man with successive torments. (Selzer writes a fine essay on the once-dreaded "Stone.") Every era, of course, has its tormenting maladiescancer and insanity are the familiar modern plagues-but we have managed a peculiar refinement upon disease. We sleep through harrowing operations; we soothe our conscious hours with utopian chemicals, often designed to simulate unconsciousness. Pain is understood mainly as something to be gotten rid of. Tolstoy's Ivan Ilych at the approach of death screamed continuously for three days in a voice so terrible that you could not hear it through two closed doors without horror. (This was a passage to enlightenment.) Today, while under-developed nations battle starvation, Western man is astonishing for how many of his fellow countrymen, at any single moment, are free from the intensest suffering of hunger, injury, and disease. A numbness to pain has become (in ways historically unprecedented) our habitual state. Into this analgesic world, pain intrudes with the sudden shock of authenticity, as if nothing in human life were so real, so believable. We know we are in pain, even if we inhabit a universe of doubt. The unexpected intrusion of pain, like an ingot hissing deep within the abdomen, seems almost a reminder of forgotten knowledge. 
In "The Hartford Girl" Selzer takes his subject from the newspaper rather than from the hospital. He quotes a clipping which contains the following account: "A sixteen-year-old girl slashed her wrists and arms and then rushed to the steps of a Roman Catholic church poking a razor to her throat while a crowd of three hundred persons cheered and screamed, 'Do your thing, sister." Like the hospital, the newspaper is a cultural repository for vignettes on the indifference and brutality of urban life. Selzer avoids the trap of cliche by implicating his narrator in the scene as a fascinated voyeur. Unable either to intervene or to stop watching, the narrator witnesses more than a senseless parable of modern horror. In their Dionysian frenzy, the citizens of Hartford reenact a form of primitive rite. Memories of blood sacrifice work like an aphrodisiac as the crowd surges round the girl, exposing what the narrator calls "our changeless ancestral themes." At last she collapses. After the tardy officials of reason (a priest and policeman) remove her, people still linger, murmuring, bending toward the dark blood-pooled steps, but now "strangely spent, melancholy"- as if drained of their sudden and archaic lust. The narrator, understandably, finds it difficult to release his thoughts from the abhorrent yet mesmerizing spectacle. Less understandable is the abstracted comment which the girl evokes in his final two sentences: "It is months later. Still, whenever I think of beauty, I think of her."

What idea of beauty is it, we must ask, which coincides with the image of a suicidal girl dazed and bleeding before a savage crowd? The question proves central to much of Selzer's work.

Pain is the unlikely medium through which Selzer attempts to recover some of the ancient resources of beauty. Burke had annexed pain to the sublime (with its new glorification of everything vast, obscure, wild, infinite, overpowering, and terrible), leaving beauty to command the softer feelings and forms. Beauty and pain, for Burke, occupy divided worlds. A glance backwards can indicate the force of Burke's influential division. Aristotle, who for over one thousand years provided the standard physiological account of pain, offered in his Poetics a theory of tragedy in which pain and beauty achieve a subtle, necessary concord. Through a catharsis of pity and fear, pain ultimately carries the spectator to a state of intellectual, emotional, and aesthetic clarification. Knowledge and beauty replace the confused accidents of history, and it is pain which provides the essential raw material for the transmutations of tragic art.

Selzer, in exploring the buried connections between beauty and pain, enters a region which most readers have never viewed first-hand: the inside of the 
human body. This inner landscape, luxuriant with mystery and danger, is closed to all but the surgeon, whom Selzer represents as a kind of priestly naturalist: "A surgeon, who feels the slow slide of intestines against the back of his hand and is no more alarmed than were a family of snakes taking their comfort from such an indolent rubbing. A surgeon, who palms the human heart as though it were some captured bird." As often, Selzer's prose internalizes the familiar world of nature and transforms it into images of strangeness, reflecting the surgeon's access to a secret, cognate understanding. Through a novitiate of special training, the surgeon (like the priest) is separated from the laity by virtue of forbidden knowledge: "At last one emerges as a celebrant, standing close to the truth lying curtained in the Ark of the body." Yet the mysteries revealed to the surgeon prove unremittingly secular: "There is no wine, no wafer. There are only the facts of blood and flesh." In the damaged and perilous interior of the body, in the space abandoned by metaphysics and outlawed by taboo, Selzer discovers the origin of a strenuous aesthetic. Gazing at our most intimate deformities, he finds in fat and fluid and tissue and bone-in man as sheer mass and matter-the potential for a beauty Burke would not instruct us to discover. Brutal and plain and painful facts always possess for Selzer the possibility of transcending themselves. "To perceive tragedy," as his (Aristotelian) narrator remarks of our capacity for vision, "is to wring from it beauty and truth." Beauty, for Burke, is subject to laws of form and sensation. For Selzer what beauty requires is an act of human understanding.

The body-inside the body-is where for Selzer our understanding of the beautiful begins. Like Whitman, whose rhythms and phrases occasionally surface in Selzer's prose, he brings us back to the body as mystery and fact. We learn to know ourselves in a new dimension. And it is through this fresh encounter with the body-especially as the scene or locus of pain-that Selzer brings us to question what might constitute beauty. It exists here, deep in the black cavities of matter, or nowhere. Beauty, as we learn the contours of Selzer's aesthetic, cannot separate itself from the vision of a "bloodless limb turned rotten and festering." It is not a quality of form but a quality of vision: a way of seeing, of feeling, of understanding. We may come to recognize it in the speechless and savage passion which binds a father to his blind, malformed son. We must, if we can, accept it in the desperate rage and exhaustion which drive Selzer's protagonist to sew the head of a violent patient to the mattress, passing heavy stitches through each ear lobe, so that surgery may continue. Our conventional (Burkean) sense of beauty often defeats love by creating an automatic recoil from images of deformity and pain. The surgeon's dispassion is not simply an instrument, as crucial as knife or clamp, for working daily amid the terrors of disfeatured flesh. Selzer writes of the surgeon's knife as almost an extension of his body_-surgery as a pitiless act of love-and dispassion 
becomes the vehicle of an intimate and inaccessible knowledge. It is the poetgifted with language as well as vision - who becomes Selzer's model of the true physician: "the poet who heals with his words, stanches the flow of blood, stills the rattling breath, applies poultice to the scalded flesh." Some poets may find this description of their craft extravagant. Selzer, however, holds to an ideal which defines poetry-like medicine at its best-as a discipline of understanding and vision, which can recognize in mute, inexplicable pain the possibilities of knowledge, healing, and beauty.

The medical understanding of pain is in its infancy. Indeed, medicine is just beginning to enlarge its view of pain as something beyond the most common symptom of illness: "an unpleasant sensory and emotional experience associated with actual or potential tissue damage, or described in terms of such damage" (IASP Subcommittee on Taxonomy). The recent development of "pain clinics" offers a new forum for considering pain not as the sign of something else (a traditional symptom referring to a hidden source) but as the thing itself. It imparts to pain a new ontological status. Pain becomes the primary phenomenon to be studied and treated and understood-while the disease to which it may or may not refer is secondary. It is mainly chronic pain (as distinguished from acute pain, whose duration is limited and etiology clear) which is now under study. This study is especially difficult because, while pain centers us in the body, even the authors of the standard definition allow that pain is "always subjective" and "always a psychological state." Chronic pain seems to suffuse the uncharted spaces where body, mind, and emotions intersect. How do we begin to know such an amorphous creature? How do we separate pain from the other demons-guilt, fear, depression, terror, desire-which share its dominion and perhaps give it visible shape? What kinship exists between the experience of Lear as he holds the body of his murdered daughter Cordelia and the patient who reports violent pain in the space once occupied by an amputated limb? Such questions may direct us-as does Richard Selzer-to a study no less crucial to doctors than to writers. What happens to us (what changes do we undergo?) when we enter the subjective and psychological body of pain?

Selzer offers us at least one firm answer. We gain access to a new manner of speech, almost a new linguistic system. As his narrator says with the brevity of one who knows: "Pain invents its own language." This unfamiliar tongue expresses both a new range of experience (for which our normal words prove inadequate) and the separation which divides every patient from the world of health. It delineates the borders of a private experience from which all but the sufferer are shut out. Pity and compassion may comfort both the patient and the comforter, but they provide no reliable entry into the individual world of 
pain, which they merely circle, endlessly. (As Wittgenstein asserted: "Pity, one may say, is a form of conviction that someone else is in pain.") The narrators in Selzer's writing are empathetic figures-acute in their awareness of sufferingbut they too share a curious detachment as spectators. Reading Selzer is to understand how seldom even the most heroic physician manages to penetrate, inside, the suffering of another human being. The best of us, as can be said of Selzer's narrators, are concerned observers, not native speakers, in the region of another's pain. We hear a strange language spoken which we cannot quite understand. "Never mind," advises Selzer's narrator, "we shall know it in our time."

$\mathrm{V}$

The failure of language, in the presence of extreme pain, is a serious obstacle to diagnosis and treatment, giving rise to elaborate medical questionnaires which attempt to locate what is essentially wordless on a grid of metaphorical terms. Is your pain pulsing, flashing, stabbing, sharp, crushing, wrenching, hot, dull, taut, exhausting, suffocating, terrifying, cruel, blinding, unbearable, penetrating, tearing, cold, or dreadful? The question seeks to make us the spectators of our own pain. We experience the physician's puzzled view from outside. Yet, pain is sometimes the occasion for a relationship between surgeon and patient which ultimately, in Selzer's fiction, makes detachment impossible. In "Sarcophagus" the patient remains unconscious throughout. "We do not acknowledge his struggle," explains the surgeon-narrator. "It is our own that preoccupies us." The patient's pain, now blocked by anesthesia, gives way to the painful dilemma of the surgeon who attempts to heal him.

In "Sarcophagus" the narrator-surgeon confronts a situation beyond healing. A cancerous aorta ruptures during exploratory surgery. The surrounding tissue crumbles with tumor, preventing all efforts to repair the irreparable damage. "There is nothing to do." Nothing, that is, but decide to shut off the oxygen. "It is the act of an outlaw, someone who does not know right from wrong. But I know. I know that this is right to do." After excruciating minutes the patient dies. At issue, however, are not the familiar, tangled questions of medical ethics. The moral or legal implications of the surgeon's act interest Selzer less than a kind of primitive transference, as in voodoo or black magic, wherein pain shifts its location from patient to doctor. "It was terrible," confesses the surgeon, "his refusal to die." The pain now has embedded itself within the surgeon-it is his terror-and detachment, like dispassion, cannot be maintained. His participation in the terrible intimacy of death dooms him to further struggle as he works over the events which so unexpectedly have claimed him, too, in their pain. Yet action, like language, seems to recede toward a realm of the private and incommunicable. It is as if meaning cannot be brought back, to our garrulous world of health, from a region so utterly primitive, alien, silent, and stark. "I close my eyes and see again the great pale body of the man, like a white bullock, bled. The line of stitches on his abdomen is a hieroglyph. Already, the events of this night are hidden from me by these 
strange untranslatable markings." It is the nature of their work-not their temperament-which transforms so many of Selzer's surgeon-narrators into solitaries.

Pain initiates us into a new-or forgotten-knowledge. It beholds, at its most intense, an unknown world of its own construction.

When, in the final act, after his visions of solace have been shattered, Lear enters carrying the body of Cordelia, it is a moment of inconceivable pain. In this extended moment of blind agony Lear utters but three words, a single, repeated monosyllable: "Howl, howl, howl!" (V.iii.258). The speech seems composed of imperatives, like his opening commands addressed to his daughters and attendants, kingly discourse. But at least one director has interpreted Lear's three words differently. Lear, in this version, is not issuing commands, not even impersonal orders, as when earlier he had commanded the winds, cataracts, and hurricanes. The word "howl" is not spoken as a command; instead, Lear howls it. Language is no longer a form of social ceremony or mode of reference. It is an action, a lone howling, a reduction of speech to its most primitive kinship with animal cries. Its desolate repetition bears no similarity to the fractured sense and syntax of his intermittent madness, which still acknowledged a world of shared experience. Imagine a world in which there is nothing but pain. How would we speak of it? How endure it? For its duration, which can seem endless, Lear's howling suspends all movement, all speech, all thought. Holding his daughter in his arms, the old king stands as a visible icon of pain, intolerable and incommunicable.

The relation between beauty and pain does not offer comforting insights. In addition, Selzer's genre is the brief story, the essay, the prose fragment, the pensée, the sketch, where neither character nor action finally sustain us. A certain bleakness and shock are costs necessarily exacted by his vision and forms. What is characteristic of Selzer's bleakness, however, is the suggestion that pain can lead us beyond its own dark privacies. It is as if only through pain can pain truly be transcended. Unlike Beckett, whose speakers increasingly lose contact with their own anatomy, Selzer creates a fiction where only in and through the body is knowledge possible. His is not a slow and reflective literature of ideas. His stories generate such immediacy, speed, and suspense as to seem, on the contrary, all plot. Certainly the possibilities of knowledge and of beauty which he makes available are not for the tender-hearted. But an aesthetic which can gaze into the wreckage of human tissue, in order to secure its deepest values, offers us something less brittle than formalism. Selzer takes us forward and back, well beyond Burke, to a region where beauty and pain begin to recover, together, their lost heritage of meaning. 